Tristan Schultz is an Aboriginal and Australian designer, strategist, and researcher examining intersections between decolonial thinking, ontological design, and sustainability. He holds a B. Design, M. Design Futures (Hons) and is a PhD Candidate, a lecturer in the Design Program at QCA, Griffith University, and founder of the design practice Relative Creative. tristanschultz1@gmail.com

Danah Abdulla is a designer, educator, and researcher. Her research explores design cultures and possibilities of design education in the Arab world. She is a Lecturer on the BA (Hons) Design Management and Cultures at the London College of Communication, University of the Arts London. d.abdulla@lcc.arts.ac.uk

Ahmed Ansari is a doctoral candidate in Design Studies at Carnegie Mellon University. He is currently working on reconstructing a South Asian philosophical genealogy of technics, and tracing histories of design education

in Pakistan. He teaches seminar courses in systems thinking, critical and cultural theory, and philosophy of technology at CMU. aansari@andrew.cmu.edu

Ece Canlı is a design researcher and artist, investigating the relationship between body politics and material practices from a decolonial queer feminist point of view. She recently completed her $\mathrm{PhD}$ in the Design program at University of Porto, fully funded by Fundação para a Ciência e a Tecnologia (FCT). ece.canli@gmail.com

Mahmoud Keshavarz is a postdoctoral researcher at the Engaging Vulnerability Research Program, Department of Cultural Anthropology and Ethnology, Uppsala University. He has been a Visiting Scholar at Parsons School of Design and University of Gothenburg. $\mathrm{He}$ is the author of The Design Politics of the Passport: Materiality, Immobility and Dissent, forthcoming with Bloomsbury Academic. mahmoud.keshavarz@antro.uu.se

\section{What Is at Stake with Decolonizing Design? A Roundtable}

\author{
Tristan Schultz, Danah Abdulla, \\ Ahmed Ansari, Ece Canlı, \\ Mahmoud Keshavarz, Matthew Kiem, \\ Luiza Prado de 0 . Martins and \\ Pedro J.S. Vieira de Oliveira
}

ABSTRACT This roundtable was conducted by the eight founding members of Decolonising Design Group in October 2017, using an online messaging platform. Each member approached design and decoIoniality from different yet interrelating viewpoints, by threading their individual arguments with the preceding ones. The piece thus offers and travels through a variety of subject matter including politics of design, artificiality, modernity, Eurocentrism, capitalism, Indigenous Knowledge, pluriversality, continental philosophy, pedagogy, materiality, mobility, language, gender oppression, sexuality, and intersectionality.

KEYWORDS: Design Studies, decoloniality, ontological designing, pluriversality, Global South 
Matthew Kiem is a Sydney-based designer, researcher, and educator. He has recently completed his PhD at Western Sydney University on the topic of the Coloniality of Design.

His thesis examines the meaning of ontological designing in light of decolonial thinking, with a particular interest in the settler colonial dynamics of

Australia. mnkiem@gmail.com

Luiza Prado de O. Martins is a Brazilian researcher and artist. Her work looks at questions of gender, technology, and the body. She is one half of the artistic research duo "A Parede" and holds a PhD in Design Research from the University of the Arts Berlin. luiza@a-pare.de

Pedro J.S. Vieira de Oliveira is a Brazilian researcher and artist in sound studies. He holds a PhD in Design Research from the University of the Arts Berlin, and is one half of "A Parede." pedro@a-pare.de

Check for updates

\section{Matthew Kiem}

Let's begin by discussing what each of us understands to be at stake in the idea of "decolonizing design." In some of our private discussions we have noted that the concept of "decolonization" is gaining currency within the academy generally and in various ways throughout the field of design. While I am sure most of us would agree that a growing awareness of and interest in the issues associated with coloniality is generally welcome, there is nevertheless a lot that hinges on the way this occurs. Our conversations have included, for instance, a concern with the tendency of political terms such as "decolonization" to be hollowed out by a pluralistic mode of engagement (see Fry 2011).

Academics and designers are adept at mimicking the representational dimension of movements - "political or otherwise" - without necessarily generating or supporting the substantive changes that political concepts are designed to bring about. This is less a problem of individual failing than it is design of the institutions that we work for. In most academic contexts, it is all too easy for people who possess a great deal of cultural capital to make the token gesture of learning a new set of terms or adding a few different texts or examples to the curriculum. While change must begin somewhere - and token inclusion is perhaps better than no inclusion at all - the problems connected to the concepts of modernity/coloniality/decoloniality and, I would add - invoking Tony Fry's term - defuturing, demand a sense of purpose and dedication that implies a far more radical and substantive redesigning of the dominant cultures of design practice, research, and education than most people have been able to register or enact.

This problem is related to Cameron Tonkinwise's (2015) critique of the proliferation of qualified versions of design, which prompts us to consider the utility of articulating the kind of difference represented in "decolonizing design." With this in mind, it is important to clarify how "decolonizing design" aims at something quite different from an additive inclusion into Design Studies as it already exists. By my reading, "decolonizing design" is not a "new" or an additional form of design but a political project that takes design as such - including its theorization - as both an object and medium of action. Considering this, it would be a mistake to assume that "decolonizing design" represents some kind of service offering, as though the field could undergo a procedure by which the "bad" colonial bits could be isolated and removed without disturbing the core business of what "design" and "Design Studies" is supposedly all about. In this sense, "decolonizing design" is not a question of improving the status quo but a question of learning to differentiate between designs that facilitate the productivist drive towards devaluing and appropriating human and non-human natures, and designs that facilitate a process of delinking and redirection into other modes of being/becoming.

As writers such as Angela Mitropoulos (2006) and Walter Mignolo (2011) have said in their own ways, the political substance of this lies less in the content of any discussion - a question of saying or including the right things - than in the terms under which the discussion is 
conducted. In other words, it is a question of who controls, profits from, or is protected (or not) by the ways in which intellectual and other forms of re/production and consumption are organized. This introduces an imperative to assert the difference of "decolonization" as a specific and fundamentally radical political project vis-à-vis the "business as usual" of the design and academic professions. Frantz Fanon $(1971,27)$ for one was very clear on this point: insofar as it sets out to change the "order of the world," decolonization is "a programme of complete disorder," that is to say, something that seeks to challenge, upset, and reconfigure modern/colonial institutions rather than fit comfortably within them. The imperative here is not so much to defend the singular or ahistorical "truth" of "decolonizing design" but, rather, to design meaningful material-symbolic change that is neither pacified nor disabled by the colonial designs of academy.

\section{Ahmed Ansari}

I would agree with Matt insofar as "decolonizing design" is primarily a political project, but then all projects and designs are, even when they claim to be apolitical or politically neutral. However, I would like to draw attention to the fact that we are engaged in this project as designers, and therefore any engagement with articulating a relation between decoloniality and design necessitates articulating the relation in terms both poietic and praxical. For me, this means engaging with the nature of what design practice helps bring into being. Design brings into being new ontologies and ontological categories and their corresponding subjects and subjectivities. This occurs through the construction of artifice and artificiality, which is inextricable from the fact of our humanity, and is now both the medium we live in, determining the nature of our existence on the planet, and the primary determinant of our horizons insofar as we interpret our reality in the present and dream about possible and plausible realities in our futures (Arendt 1958; Dilnot 2015).

In the canon of decolonial theory (Mignolo, Quijano, Grosfoguel, etc.), the current incarnation of the project of continued Western coloniality over the rest of the globe through the mechanisms of globalization and neoliberalism, there is little attention to the development of artifice as a necessary condition of modernity. In other words, decolonial theory lacks any substantial theoretical reflection on the history of the artificial as it developed after the Industrial Revolution from regionally bound, culturally specific technical trajectories into a global technical system; the role that artifice has played in giving shape to and sustaining and perpetuating forms of colonial power; and the nature of the artificial especially as it relates to ontological differentiation. Apart from Arturo Escobar's (2012) Notes on the Ontology of Design, Mignolo, Quijano, and other decolonial scholars have instead traced histories of power. As a result, designers have very little to go on in the way of thinking about design's relation to the problem of modernity. 
I would add that there has been some considerable work on modernity, artificiality, and on specific manifestations of colonial power through artifice in academic disciplines like material culture, anthropology, science and technology studies, and development studies. But design discourse has done little to incorporate these accounts. As I see it, the present project of decolonizing design requires a threefold move. We first need an account of the artificial and of the condition of artificiality, an account which can explain the different sociotechnical trajectories that various civilizations exhibit up until modernization through colonialism and globalization. We must then situate this account in relation to the problem of modernity and the modern world system, in order to develop it into something that explains what the technical foundations of modernity are. Finally, we can turn to the consideration of other, possible artificials - of alternatives to the systems of technics we have today. This is the nature of the project that I have undertaken over the past few years.

This task cannot be undertaken solely through the lens of contemporary Western thought, even if this lineage of thought has problematized the very modernity it birthed. It must be thought through looking from the lens of the more marginal perspectives of: the ex-colonized (i.e. new, hybrid subjects that so eagerly embrace globalization); the extra-colonial, (i.e. those rare Indigenous peoples that live on the outskirts of the world-system and tenaciously preserve ways of being that have otherwise died out in the world); and the subaltern castes (i.e. those who have been "left behind" by modernity, never sharing in the privileges and spoils of becoming modern while nevertheless forming the living reserve that fuels the mechanisms of the neocolonial world-system). To think beyond modernity from within modernity is not an easy task. But it is only when we incorporate these marginal perspectives into a reflection on the nature and history of modernity and of artifice to try and understand how it is that plural cultures were drawn into the binary of center and periphery, that we can then begin to tackle the productive task, from each of those peripheries, of designing plurally again.

\section{Tristan Schultz}

I too have noticed the currency of the term "decolonizing" being reduced to a hollow gesture. I fear it is traveling in a similar direction to the way the term "sustainability" was co-opted for neoliberalist means in design. In the last few years, decolonizing practices and movements have proliferated, with some fitting the kind of decolonizing design praxis I would describe as a political ontological design of plurality for sustainment, and others not. The latter are, at best, a token gesture of learning a new set of terms. They perpetuate neoliberal globalizing and homogenizing ambitions by pandering to an ontological elimination design event of the technological colonization of imagination. Because of the industrialization of memory through socio-communicative digital technologies, people's abilities to imagine being otherwise is being 
eliminated (Escobar forthcoming; Fry 2012, 2017; Stiegler 2009; Virilio 2008, 2012).

There is currently not enough critical reflection on this in the interrogation of coloniality in design, nor is there enough self-reflection on the techno-mediating methods through which "decolonizing" design is explored. In late 2016, I collected a list of invites and call for papers that proposed decolonizing modernism, theology, computing, technology, the arts, love, gender, and, of course, "all things." There have been several summer schools, book series, and efforts to decolonize design thinking too. Of course, our own platform, decolonizing design, is part of this phenomenon.

Arturo Escobar (2017) writes that the ontologically designing techno-mediation of worlds has now become a question of survival for the autonomy of all those people who never signed up to "being" culturally commodified universalized hyperrealities (Virilio 2012). This leads me to wonder if we might use design education that takes seriously the destruction of biophysical worlds (sustainable design, eco design) as a model for design education that takes seriously the destruction of human lifeworlds and autonomy from excessive techno-mediation. Can design education take an ontological turn to squarely focus on techno-mediations as they relate to designing autonomy and plurality and to futuring? Decolonizing design, as Matt suggests, demands an urgent recognition of the threat defuturing techno-mediation poses to our sheer existence as a species (Fry 2017). All this amounts to a task no smaller than locating how designers can be decolonized, enabling an aptitude to prefigure, project, and future being human. It invokes a politics no smaller than the Enlightenment, even though the hegemonic ambitions of the Enlightenment are precisely what decoloniality must reverse.

This connects with Ahmed's "threefold move" proposition. But I would say that to situate problems in relation to modernity and consider alternative systems to the technics we have today requires breaking free of the rationalistic Cartesian worldview that colonizes all of "our" minds and places us on a spectrum of ontologically conditioned modern world system beings. As Boaventura de Sousa Santos (2014) has noted, we are facing modern problems for which there are no modern solutions. We lack the ability to organize thoughts in such a way that we can comprehend, in different modalities of temporal and spatial scale, our situatedness amongst a maelstrom of ontological plurality. Even worse, we designers with our designerly tools, methods, and mapping techniques risk un-mapping plurality. What I mean is we risk doing the reverse of what Escobar $(2015,15)$ calls the mapping of "multiple transition narratives and forms of activism ... veritable cultural and ecological transitions to different societal models, going beyond strategies that offer anthropocene conditions as solutions," by mapping social messiness into rationalist Cartesian and instrumental typologies of convenient commensurability to modern world-system minds. Decolonizing design first requires unlearning defuturing mapping traps in order to learn mapping relational worlds. This relates to Matt's point 
about "learning to differentiate" relationally. As Auntie Mary Graham (2017) speaks of Aboriginal relationality, from where she is located, as a Koombumerri Aboriginal Elder (Australia), there is no Aboriginal equivalent to the Cartesian notion of "I think therefore I am" but, if there were, she says, it would be I am located therefore I am. For Mary, location or more poignantly Place - equals Dreaming. There are multiple Places so there are multiple Dreamings, so there are multiple Laws that equal multiple Logics that equal multiple Truths. All Perspectives (Truths) are valid and reasonable. This is not relativism because there is still judgment emanating out of a locality in a reciprocal relation with land, place, ethics, balance, and autonomy. For me, this intelligible Aboriginal philosophy is 65,000 years older than the core condition Tony Fry (2009) argues for - a limitation of freedom within sustainment. Mapping and amplifying the futuring and eliminating the defuturing techno-mediations and socio-technical systems performing on these kinds of Aboriginal relational worlds could be an immensely significant contribution to decolonizing design because it is a contribution to futuring humans (in all ontological pluralities) and the biophysical worlds upon which humans depend.

\section{Matthew Kiem}

Tristan mentions the significance of distinguishing the concept of plurality from both relativism and pluralism. This strikes me as a key part of what decoloniality means as a mode of designing. In this regard, I can appreciate something of Ahmed's dissatisfaction with how decolonial theorists have understated the significance of technics, particularly as there is a specific way in which a designerly interest in the politics of material-symbolic configurations forces important and inescapable questions of decision, direction, and relation. Indeed, I have often wondered about the emphasis that decolonial thinkers have given to questions of epistemology over ontology. I do not want to overwork this distinction - it is after all but one of many ways of organizing (designing) a line of questioning - but in the context of my interest in thinking about ontological designing in light of decolonial thinking, it does strike me as significant.

The largely ambivalent and sometimes hostile treatment that the concept of ontology receives in the work of such thinkers as Dussel (2003) and Maldonado-Torres (2007) is at least in part related to the strong stance that Levinas took against aspects of Heidegger's thought that Levinas understood to be indivisible from Heidegger's fascist politics. Connecting the question of theory to politics and personal relations in this way does nothing to undermine the significance of what is it stake for either Levinas, Dussel, or Maldonado-Torres but, on the contrary, provides a clue to what they are trying to accomplish through the critique of concept that has otherwise been significant to theorists of ontological designing (Willis 2006, n.d.), decoloniality (Escobar 2012), and Indigenous design philosophy (Sheehan 2004). 
In the face of these differing positions on some of the philosophical fundamentals, I have found it useful to consider plurality as a materialist concept, that is to say, that plurality "is" and affects (designs) "us" in excess of the representational terms through which it is thought (Deleuze 1995, Sheehan 2004). This is not to say that ideas are not important but that their agency is best understood in material terms (Mellick Lopes 2005; Rooney 1989). Whereas the philosophical idealist sees danger in the expression of a difference that refuses to fit within (their materially specific) mode of configuring representational thought, a materialist conception of plurality shows that political contestation is grounded in the ways that things and relations are designed (Sheehan 2004). While the question of distinguishing colonizing designs from decolonizing designs is necessarily a question of situational and perspectival discernment, what I am trying to suggest here is that: 1) situational epistemologies/ontologies are relational, not relativist; and 2) the question of the pluralism is an issue of anti-relational (colonial) designing that can be addressed by learning to discern the presence and possibility of designs for relational plurality. To my mind, these are the terms by which the works of Indigenous philosophers such as Graham and Sheehan show up as expert expressions of designing otherwise and beyond the coloniality of knowledge, as opposed to having their work rendered as exoticized targets of the pluralist desire for inclusion, alias assimilation.

\section{Ahmed Ansari}

Matt's observation that ontological questions are received with somewhat more suspicion in Latin American scholarship is interesting and, perhaps regionally specific - I can certainly trace subtle but important differences between the scholarship coming out of Central and South America and, say, South and East Asian authors. I do think that the very different ways in which colonialism arrived and then perpetuated between various regions of the world have led to very different framings of the problem of coloniality/modernity. This means that there is no one approach to a decolonial politics but, as both of you have pointed out, a plurality, many possible politics.

For example, unlike the first conquistadores in Latin America, who arrived as military men backed by Spanish guns, cannons, and clergy, the British and Dutch arrived as traders not conquerors in India, China, or the Southeast Asian kingdoms. Nor did colonial conquest proceed in the same way, one of the key differences being that there were no mass genocides and subsequent displacements by white settlers or extensive interbreeding between the settler and local populations (subsequently, one finds racial hierarchies based on different genealogies in Latin America, whereas these are noticeably absent in South Asia, where ethnicity, religion, and caste still dominate social hierarchies).

One can theorize that this form of total rupture, this total break from the Pre-Columbian past, has influenced the way that modern Latin American postcolonial identity is framed and constructed. To drive the 
point home, colonialism and modernity mean different things to different peoples and cultures, and therefore lead to different questions, concerns, and politics. The what you can reach to as the means of constructing alternatives is also regionally and historically contingent: can you reach back into a precolonial past, or is the rupture so great that this is impossible; are there Indigenous ways of being in the present that you can study, or have those cultures ceased to exist? It is therefore imperative, I believe, that designers committed to a decolonial politics do the work of delving into their own civilizational histories.

Moreover, it is worth noting that, in South and East Asian scholarship, at least, both questions of ontology and technics have received a great deal of attention, partly as a history of responses to European continental philosophy, and particularly in the early twentieth century, the German continental tradition, the influence of which on pan-Asian thought has been, I think, greatly overlooked and underrated (for example, Tetsuro Watsuji and Nishado Kitara and the Kyoto School were responding directly to Heidegger in their theorizing Japanese phenomenology and technics). Like l've emphasized before, it's not that this work is missing - it is that it has received scant attention, especially within the community of design historians and Design Studies scholars, and this is because we do not have the equivalent of the highly specialized scholars in the humanities who can work in multiple languages and immerse themselves in the histories and texts of different cultures.

This has always been one of the great failures of design history and theory - unless both can reform themselves as disciplinary practices, training a new generation of scholars who will be able to recover, derive, translate, and build canons that aren't Anglo-European, I fear that both design history and Design Studies will continue to be severely constrained in their ability to offer useful prescriptions to feed into contemporary practice. As Clive and Tony have pointed out in Design and The Question of History, design schools today only teach token history courses that focus on individual movements and their aesthetics rather than trying to build a nuanced understanding of how modern technical systems came to mold and shape modern humans (Dilnot, Stewart, and Fry 2015). It is therefore no surprise that design practice today is like a headless chicken, flailing about, trying to reconcile its own structural complicity with mechanisms of the modern world-system with the urgency of dealing with the monsters it has helped birth.

I would modify their assessment of the present situation by further stating that practice is doomed to fail because the horizons of what it knows are neither deep enough nor wide enough, i.e. it does not go far enough back in time, nor does it span space and place. Design practice has no alternatives because it lacks the very thing that makes alternatives possible: the understanding of historical and contextual difference. This is, in part, because of the failure of Design Studies and design history in both informing practice as well as in widening, deepening, and critiquing its horizons. We need to think beyond design practice to what it can be other than what it is, but we cannot do this 
without a massive shift in making history and theory relevant again, and in decolonizing Design Studies and design history.

\section{Danah Abdulla}

Matt and Tristan mention the risk of decolonizing design becoming just another design descriptor and following the same route as sustainability. This is important. Several months ago, while discussing my involvement with Decolonising Design, someone said to me "I'm going to decolonize my breakfast, it's a word you can use in front of anything." The scene reminded me of a running joke we had in graduate school when everyone was using the word "curate," and one of my colleagues once told me he was going to "curate" his breakfast. Are we at the point where decolonizing is used as lightly as "curate?" Has the term become some meaningless buzzword that can be thrown in front of anything, emptying it of its urgency?

Our task is to make sure people understand decoloniality for what it is: a subversion and transformation of Eurocentric thinking and knowledge; a knowledge produced with and from rather than about. Why then is this term not serious for others? I would like to question this. The "doing good" movement in design (social design, design activism, humanitarian design, etc.) has brought about an important questioning for designers and an interesting starting point, but has done very little in the way of transforming design education, thinking, and practice. Despite these efforts and the newfound importance attached to design, designers often remain uncritical service providers, and design itself part of a competitive business strategy. The "doing good" movement has contributed to what I call the morality aesthetic - a "style" born out of corporate social responsibility and conscious consumption. It means Adidas invites you to break the status quo, Ray Ban wants you to pitch your world-changing ideas in their \#Campaign4Change, and Doc Martens calls on you to \#Standforsomething. Other brands are jumping on the moral purity bandwagon through action hashtags and preachy copy. Like Tristan, I fear that decolonizing design is going in this direction and becoming a synonym for "improving things."

The morality aesthetic risks simplifying decoloniality and stripping it of its criticality. Just imagine: "The Decolonizing Design Toolkit" (featuring Venn diagrams, bite-size lines of inspiration, and witty one liners, set in Champion and Bryant and poppy colors) provides a step-by-step method on how to decolonize design. Or: "Now you too can Decolonize Design in six weeks! Sign-up to our new class online." Or: "Announcing a two-week summer school where designers can decolonize their designs. Location: an independent art college. Price: 22,000 without accommodation or travel." We must be careful not to move into what Tuck and Yang $(2012,3)$ call the "too-easy adoption of decolonizing discourse (making decolonization a metaphor)."

The danger of decolonization becoming a metaphor is that it will be rendered obsolete. In the Global North, and specifically in the UK, most 
universities claim that statistically what they term "Black Asian and Minority Ethnic (BME)" students underperform. Some argue for diversifying the content, while most attempt to address the issue through more tutorials and face-to-face time. However, the mere token inclusion, as Matt says, is not addressing the causes of issues. Why are these students not performing as well as others, and why do they fail to connect with the content? It is not only a content issue, but also a matter of who is teaching and how. Universities should not only look at their content, but address their hiring practices by recruiting faculty that better represents the students.

The morality aesthetic is now being implemented in design programs and design practice across the Global South. In the Arab region for example, largely middle-class design students are looking to "serve" the needs of poor communities composed of people with very different backgrounds from their own, or designing for refugees, where countries like Lebanon and Jordan have over 1 million refugees living there. Designers aim to provide a "voice" for the disenfranchised, using aid discourse, and maintaining dominance over the production of knowledge by using these communities for their school projects. These ideas and methods, disguised as "universal" have traveled, carrying with them the structures of Western thinking, and continuing to reproduce the cycle where the Westernized universities are reliant on knowledge produced elsewhere. The Westernized university features the same curriculum, the same authors, and the same disciplinary divisions that dominate universities in the West. These structures remain unquestioned: as Grosfoguel (2013) says, they become "commonsensical." This unquestioning means ideas are copy-pasted into a curriculum where knowledge and truth are masked as universalism, defined by a canon composed of works of males from five Western countries (Grosfoguel 2013), that represents 12 percent of the world's population. This is most clearly illustrated in the divisions of art history courses where Westernized universities located in Arab countries have course divisions such as "Islamic Art" and "History of Modern and Contemporary Art." Within design, we see the differentiation between "Typography" and "Arabic Typography." But are these Muslim cultures, beliefs, and institutions, as Sami Zubaida (2011) asks, so alien that they require special study and understanding? Why, then, is there a course in "Arabic Typography" or "Islamic Art" within a university located in the Arab world? Why is it not simply "Typography" or "Art History?"

I propose that to decolonize, we begin in the Westernized university, where we can begin to think of an epistemic pluriversality rather than a universal set of solutions. As Ahmed mentioned, we can not only "look through the lens of contemporary Western thought." We need to take the epistemic traditions of the Global South seriously and begin to shift the direction and decolonize "institutions appropriated by Eurocentred modernity" (Grosfoguel 2013, 88). 


\section{Mahmoud Keshavarz}

For me the urge to think decoloniality starts from two very specific and intertwined premises - my personal trajectory and my work trajectory. I will start with the first because I believe it is important for us in Decolonising Design to clarify how we have arrived at this point, in feeling the urge to start this platform of intellectual exchange and discussion.

My working and thinking has been primarily inspired by continental Western philosophy. I am trained in industrial design and grew up in Iran during the reformist era. This post-revolution era was defined by a series of student, feminist, and worker movements. Many newspapers were dominated by liberal agendas, and a number of Western liberal and continental philosophers were invited to give lectures. Their works were largely translated and published. Sometimes there was more than one translation of the same book of philosophy being published in one year! As time passed, New Left philosophers were also translated. Theoretical works produced in Europe shaped my perspectives on politics at the same time that I was trying to make sense of the street politics and how "ordinary" people push their politics in everyday life in Iran (Bayat 2013).

When I was in Iran, I read primarily Western thinkers. Later, when I moved to Sweden, I read primarily non-Western writers. This experience is not entirely unique. Famously, when Frantz Fanon, a middle-class Martinican, went to Paris to continue his studies, he was struck by an encounter which later would form the basis for one of his chapters in Black Skin, White Masks. After completing his studies in Lyon, Fanon was boarding a train to Paris and noticed a little white boy who stares at him and tells his mother: "Mamma, look! A negro. I am freightened," [sic] and the woman turns towards Fanon: "Take no notice, sir, he does not know that you are as civilized as we ..." (Fanon 1986 [1952], 111). For Fanon, this encounter points to different levels of racism as a structural drive as well as a product of colonialism and the benefits and privileges it provides for certain groups in the world. Fanon tells this story to locate his body in a world that bars him from participating in it in the way he desires or imagines. To be part of French society, he must either mimic the white body or behave like a black man as construed by French colonialism's social imaginary. Fanon (1986 [1952], 109) writes: "I came into the world imbued with the will to find a meaning in things ... and then I found that I was an object in the midst of other objects." What's more, I was struck by Fanon's willingness to share this personal experience. Such stories and lived experiences were missing from the majority of the Western scholars I had been reading. While living in Europe, I had a hard time understanding universal analysis and theorization of white Western scholars. Often posed as universal facts without bodily locations, these epistemologies persistently locate the other while failing to account for the geographical, historical, and corporal locations of the producers. Migration pushed me to read scholars who constantly locate themselves in the world. This was my personal path.

My research has also shaped my trajectory. My doctoral research project explored the material practices that shape and are shaped by 
conditions of undocumentedness, conditions of being deprived of the basic civil rights due to lack of residential permits or not having the "right" papers in crossing borders, and residing in a territory. My interest was to locate design as a specific historical and material practice that produces violent conditions of mobility and, consequently, immobility and undocumentedness. It seems imperative to think of the colonial legacies of migration, of how the current understanding and policies around migration are shaped by various colonial practices around organization of mobility. However, and surprisingly, there are very few works addressing the coloniality of the politics of movement and mobility. This is due to a form of "methodological nationalism" (Glick Schiller and Wimmer 2002) being embedded in social sciences as a specific strand of the Enlightenment. Such an attitude dominant in much of the scholarship produced by Western institutions tackles the issues of migration and mobility as an incoming phenomenon. This happens by taking the nation-state or recently a more expansive nation-state (the European Union) as the given territory from which others, their acts and agency can be interpreted. For instance, writers in the Global North have produced a massive body of knowledge about "why they come here." This perspective positions the institutions and their researchers at the center of knowledge production. This formulation selectively highlights the act of coming here as the focus of research on non-white bodies, thus producing knowledge by and for white institutions. But in reality, the process of migration contains various localities, simultaneous leaving and arriving, transition and transformation. Others have noted the coloniality of knowledge, and it is indeed true that certain epistemologies designed and continue to design themselves out of history, reserving a high ground from which other epistemologies can be seen, compared, judged, and interpreted.

As I was finishing my research, I realized that discussing the politics of design and the design of politics without discussing their colonial histories is a partial project. While it is important to account for how design and designing have shaped the way in which Europe and European citizens assume certain bodies as "legal" border crossers and others as "semi-legal" or "illegal" border crossers, it is also urgent to consider whose design (i.e. from what time and position and from where) has made and sustained the current hegemonic order of movement. Think, for example, of the Western notion of design as a task of "problem-solving." This idea assumes a universal truth in addressing the complexity of the world as a series of problems to be solved. Moreover, it assumes the position of center for itself as given, and approaches other epistemologies from that given center, trying at best to collaborate with or at worst to assimilate them.

\section{Pedro Oliveira}

I see the necessity of a decolonizing ethos within design as a process of accounting, first and foremost, for the historicizing of the field itself. The world as problem, as Mahmoud notes, which is to be "solved" 
from a single, universal "locus of enunciation" (Mignolo 2011), must be problematized in itself. Such a pre-packaging and systematization of complexity in terms that might be tackled by a single approach of "making" or "thinking through making" assumes a "solvability" which is immediately assigned to a mode of shaping the world into a certain "order": designing (which places practices stemming from industrial development as its starting point). If we recontextualize the emergence of design as a discipline within the wealth accumulated by and through the invasion and pillage of land and its resources, the erasure of Indigenous peoples and their cultures, and the forced displacement of populations and their resignification as commodities, we grasp a fuller understanding of the worldview promoted by designerly discourse. I believe that a decolonizing practice begs to directly challenge what it means to act within a set of skills, methods, and research imperatives that, by definition, stem from this colonial framework. A decolonizing ontological framework must see design as a socio-technical mechanism of inquiry, re-enunciation, and re-narration. It is a project of looking back and re-framing certain material practices, and also a project of understanding the relationality of things beyond their mere objecthood.

For me, this brings into the fore the need to position decolonizing design as a doing in both praxical and poietic terms (to recall Ahmed's point). What exactly this doing entails needs to be articulated from different standpoints. The first is to think of the designing of time: this process unfolds slowly and as a constant struggle, without necessarily reaching a "pivotal point" of a "decolonial" or "decolonized" design (Dilnot, Stewart, and Fry 2015). A decolonizing project dwells on time and moves at a different pace. It rejects the impositions of neoliberal academia and the colonial framework of result-driven, well-defined, problem-solving design. This, I think, is why we refer to it as "decolonizing" design rather than "decolonial" design. The term suggests a process, a movement without a set ending point.

The second element of this doing follows from the first. It entails decolonizing our roles in the spaces upon which we act, namely where we teach, exchange, think, and practice design. The spaces from which we think and practice design - spaces like the privileged site of academia - must represent the interests of the population whose life is most threatened by the designed engines of colonization. Decolonizing design thus becomes a question of breaking down segregated spaces within and beyond the classroom and academic circles, allowing for a "mundo donde quepan muchos mundos (a world where many worlds fit)", as the Zapatistas say (Ejército Zapatista de Liberación Nacional 1996). One way to do this is to confront the question of language, so that we learn how to speak differently and develop new "designerly" languages. There is a gap between decolonial theories and designerly work that a project of decolonizing design should address, even if it ultimately means rethinking and redesigning our relationship with designing altogether. In other words, a project of decolonizing design speaks from and fosters spaces in which many border languages emerge. 
Gloria Anzaldúa $(1987,2015)$ theorizes on the production of such border languages. She observes that there cannot be a conversation that seeks to decolonize our onto-epistemologies if the poetic, the artistic, the spiritual, and the subjective are not accepted as cogent methods of knowledge production. We need this in order to unlearn and break down the engines of colonization beyond the theoretical and academic. Anzaldúa $(1987,80)$ reminds us that "because we internalize how our language has been used against us by the dominant culture, we use our language differences against each other." In adapting our language, in becoming fluent in several "wild tongues" (1987, 76), we invite others in, exchange our different knowledges, and decolonize discourses at the moment of their very enunciation.

Decolonizing is also a prescriptive doing. Paulo Freire reminds us that prescription is a key element in the articulation of power. He argues that "every prescription represents the imposition of one individual's choice upon another, transforming the consciousness of the person prescribed to into one that conforms with the prescriber's consciousness" (Freire 2000 [1970], 46-47). Design normalizes these prescriptions, and the work of design, even when practiced with a supposedly "sociallyconscious" mindset, ultimately follows "the guidelines of the oppressor," teaching designers to assume the world as a well-defined set of problems to be solved. Instead, designers must understand that the very notion of the "world-as-problem" is an assumption worth challenging.

I see decolonizing design as a project that promotes an ontological change in how design is understood. Decolonizing design does not aim to create an opposition between "decolonized" and "colonized" designers or design practices. Rather, it promotes the ontological changes that will allow us to design more time for ourselves in this world. It is a project of incompleteness, of persistently un-learning and re-learning to see the world. We must constantly interrogate not only the field but also ourselves and our own practice; in so doing, we move beyond inquiring who is offered "a seat at the table" (to use Solange Knowles' language; Knowles 2016) but also the very terms used to set this "table."

\section{Tristan Schultz}

Pedro notes that the project of decolonizing design dwells on time and moves at a different pace, which rejects the impositions of neoliberal academia and the colonial framework of result-driven, well-defined, problem-solving design. This is important. As Fry (2009) has mentioned, the university can be traced back to the fifth century with the Nalanda University in Patna, India, one of five Buddhist centers of learning. From a Western perspective however, the university began in Bologna and is less than 1,000 years old. Apart from a rich discussion to be had here related to modernity appropriating the locus of the birth of ideas and knowledge, what I would like to bring in to focus is the sheer amount of time it took for the university as it is currently known to mature and become a defuturing institution. Can paths shift such that 
the university becomes a futuring institution within the next hundred or so years? There's a tension here: on the one hand, the re-making of the university, urgently needs to unfold; on the other, this remaking needs to patiently unfold over an indefinite period of time.

An urgent patience in which people (particularly in the Global North) require giving over to a condition beyond the modern rational appetite to become, and give in to a becoming, an always moving, a working with what remains, while never arriving anywhere new. How can we, as designers, balance this urgent patience with the imperative of acting (designing or eliminating designs) swiftly toward the establishment of ontological designs that perform directionally toward viable human futures before "we" (humans) anthropocentrically accelerate our demise?

\section{Luiza Prado}

Ahmed and Danah point out that we cannot look only through the lens of contemporary Western thought. How are we, as scholars invested in the decolonial project, immersed in the very structures we want to challenge? How does this often manifest in insidious ways, and in our own discourse?

In the struggle for decolonizing design, I believe it is fundamental that we acknowledge and challenge the ways in which coloniality's hierarchical classification of subjectivities shapes our perception of which subjects are permitted to enunciate and produce knowledge. Ramón Grosfoguel $(2011,71)$ points out that the global gender hierarchy and the global race hierarchy established by coloniality cannot be thought of separately; it is through the intersection of these facets of the colonial project that white women come to "have a higher status and access to resources than some men (of non-European origin)."

Maria Lugones (2007) argues that the emergence of a colonial/ modern gender system is foundational to the enactment of colonial power. She identifies within this system a "light" side and a "dark" side. The "light" side concerns itself with hegemonic constructions of gender and sex/sexuality, and pertains to "the lives of white bourgeois men and women" $(2007,206)$ while simultaneously constructing these very categories. The "dark" side regulates the lives of those subjects that exist outside or at the margins of the white, bourgeois, heteronormative patriarchy. Although both "light" and "dark" sides of the modern/ colonial gender system are violent, Lugones stresses that this violence is manifested and enacted in fundamentally different ways. The gender system positions all women as closer to the realm of nature than to that of culture. White womanhood is associated with innocence and respectability, and white women are charged with the task of perpetuating the white race within the nuclear, heterosexual family, while non-white womanhood is animalized, "marked as female but without the characteristics of femininity" (2007, 202-203). Non-white women thus come to be associated with sexual perversion, so validating the rape and sexual exploitation of non-white women within the modern/ 
colonial gender system. Inevitably, the violence imposed by this gender system spills into how design engages with the body: its articulation of modes of being made by and in the world - what Anne-Marie Willis (2006) calls ontological designing - is, after all, also implicated in the articulation of how gender is made, performed, and embodied in the world. It is in provisional acts of materialization, of mattering (Ahmed 2008,33 - a process inextricably entangled with the material world that gender comes into being, and "becomes worldly."

Scholarship on precolonial social structures provides useful glimpses beyond this modern/colonial gender system. Feminist scholar Oyèrónkẹe Oyěwùmí (1997), for instance, remarks that gender was not a structuring principle in Yorùbá society prior to the contact with European colonizers: language and given names were gender neutral, and there was no concept of opposing, binary, hierarchical genders. Yet, European colonizers, presuming the universality of their own mode of social organization, described Yorùbá society as if gender were, indeed, perceived along patriarchal, dimorphic lines. This triggered profound changes in Yorùbá society; it is in response to European biological determinism that the "body-reasoning" (Oyěwùmí 1997, 5) of Yorùbás shifted, and bodies marked as feminine came to be coded as hierarchically inferior, subaltern.

Lugones $(2007,188)$ reminds us, however, that such a profound shift cannot occur without the strategic indifference that "men who have been racialized as inferior, exhibit to the systematic violences inflicted upon women of color," and that the theorization of "global domination continues to proceed as if no betrayals or collaborations of this sort need to be acknowledged and resisted." I bring this up because I believe that decolonization must emerge from an engagement with feminist and queer theories, and Lugones' critique is unfortunately very apt; the contributions of feminist scholars of color are still often overlooked, even within our group. Modern/colonial gender arrangements are also manifested in the ways in which we opt - and I use this word with an acute awareness of its weight - to engage with decolonial theories: with whose and which ideas we choose to engage, and whose and which theories we choose to highlight in our work. Who gets a seat at the table, as Pedro mentioned. Design historian Cheryl Buckley $(1986,5)$ emphasizes that the division of labor within Western design has historically been organized along the hegemonic gender binary, where women are presumed to have "sex-specific skills" that make them especially suited for work in the decorative arts, and in fields associated with domesticity such as embroidery, weaving, knitting, pottery, or dressmaking. On the other hand, fields like architecture or graphic design have historically been male-dominated. At the famed Bauhaus school, it was feared that the presence of women practitioners in these fields could "weaken" these disciplines (Ray 2001). This division of labor trickles down to the production of knowledge in design, too: male theorists still enjoy disproportionate visibility, opportunities, and respect in design academia. 
It is not enough to shift our focus from a Northern- and Western-centric perspective to one that is Southern-centric. We must also address the masculinist structures of power that govern knowledge production in design. The work of decolonization requires a profound consideration of how gender hierarchies established by coloniality affect our perception of what counts as valid knowledge, and who generates that knowledge. Decolonization is a daily practice, one that encourages us to be critical of our own, preestablished modes of acting and thinking; one that requires us to challenge how we speak, to whom we are speaking, and how. We must challenge our own standard citational politics and reflect upon whose work we choose to highlight. A decoIonial politics must be a feminist politics; otherwise, we risk reinforcing the same structures that we set out to deconstruct.

\section{Ece Canlı}

Mahmoud's emphasis on personal trajectories resonates with Ahmed's suggestion of delving into our own complex civilizational histories. To this I would add that we cannot thoroughly make sense of the ongoing effects of coloniality and its material politics without digging into our own cultural, historical, ancestral, and colonial pasts, and situating our present selves within a greater temporal and geographical context. Doing this helps us not only map relational worlds and subjectivities (as Tristan says), but also uncover, contest, and even deconstruct a myriad of identities introduced and stamped on us by the modern, colonial, capitalist world system. This approach allows us to see how our identities as, in Luiza's words, hierarchically classified subjectivities imposed by colonialism are continuously reinforced and reproduced by material practices (aka designing). Therefore, a journey towards one's own individual and collective history is also imperative for design researchers who seek to investigate socio-corpo-material conditions constituted and perpetuated by coloniality. Queer feminist thinking has taught us that this is not an easy task. It entails a great deal of selfreflection, self-redirection, and incessantly challenging one's own knowledge, subjectivity, and privileges, as well as the epistemic and ontic foundations from which these subjectivities derive. But it is worth it if it allows us to undermine insidiously manifested partialities, immunities, and relations with various axes of power.

I stress the importance of this task to amplify Luiza's points on how, although one of the main premises of decoloniality is to overthrow the hierarchical order that segregates bodies and knowledges, this order persists at both material and discursive levels, threatening to undermine our decolonizing effort. One of the threats resides in the politics of citationality. In continental philosophy and in design scholarship formed and taught by the West, "white men cite white men" (Ahmed 2014), excluding gendered, sexualized, and racialized bodies from the main philosophical and methodological discussions (Clerke 2010). But this cannot be tolerated in decolonial thought. If our desire is to avoid the discriminatory traditions of knowledge-making, we should 
constantly retrace and reformulate our own reasoning about whose voice is heard, whose knowledge is valid, and whose privileges cause others' oppressions.

Decolonizing design is also threatened by a tendency to inhabit, see, and make the world through the lens of the binary logic (i.e. man/ woman, male/female, black/white, inferior/superior, primitive/civilized, culture/nature, ontology/epistemology, West/East, etc.). A decolonial approach must undermine stark oppositions that marginalize the subjectivities and epistemic traditions inferiorized by modernity. A decolonial approach must uncover other ways of being, such as in-between or on the borderlands, as Pedro suggested. However, even we researchers with decolonial agendas tend to repeat these binaries. For example, we regard the relationship between the colonized and the colonizer as though there is one external malevolent colonizer from the Global North and one exploited yet benign colonized of the Global South. The story, as we know, is much more complicated. We cannot ignore the complicities and power interests of the colonized, nor many different forms of subjugation between the oppressor, oppressed and inter se, especially when it comes to gendered and racialized bodies residing at the lowest levels of the hierarchical power. In the prologue of the documentary film Concerning Violence (Olsson 2014), Gayatri Spivak similarly speaks of how gender oppression has been overlooked in the discourse of decoloniality and how in the violent process of gendering, the colonizer and the colonized act(ed) as allies. Her utterance evokes similar queer, decolonial critiques of how Western-oriented gender and sex categories have benefited not only the white colonizer man, but also the colonized man who savors the privileges of heteropatriarchy and heterosexism introduced to him (Lugones 2007; Oyewùmí 1997). At the same time, the gendered and racialized body is dominated by its Western counterparts (i.e. "whitestream" neoliberal queers, women, feminists) through altruistic attempts to save the latter from "monstrous" and "uncivilized" non-Western males (Petzen 2012). What's more, by dooming subaltern knowledges, agencies, and materialities to inferior status, there is a perception that they must be validated by the West (in this case Western gender and sexuality discourse). Otherwise, as Danah mentioned, their struggles and wills are deemed illegitimate (Abu-Lughod 2001). As decolonial researchers, we need to be aware of if and how we trigger structures of dominance in our professional and personal lives.

We might thus think of decolonizing design praxis, research, and pedagogy not only as a form of "doing" (as Pedro suggested) but also as form of "undoing," as an act of passivating, unravelling and no longer contributing to material-discursive configurations that privilege certain bodies while oppressing and dehumanizing others. Such efforts to undo can be understood as both a precondition for and consequence of unlearning. And for us, as designers and researchers, this unlearning can only arrive through "de-linking" not only from the ideas and methods taught by the holders of material and epistemic power, but also from the humanitarian design endeavors that other the others 
further and replace a multiplicity of voices with tokenism and diversity. We cannot be freed from the material and onto-epistemological subjugation of the Global North without constantly contesting our own positionalities and privileges.

This, together with the previous accounts in this roundtable, might answer one of Matt's initial questions on how "decolonizing design" would be different from being yet another additive category in Design Studies. If we cannot fulfill the imperative tasks we have hitherto propounded, not only the term but also the effort of "decolonizing" is doomed to be hallowed, forgotten, and replaced by other newcomer labels for design.

\section{Disclosure Statement}

No potential conflict of interest was reported by the authors.

\section{References}

Abu-Lughod, Lila. 2001. "Orientalism and Middle East Feminist Studies." Feminist Studies 27 (1): 101-113.

Ahmed, Sara. 2008. "Open Forum Imaginary Prohibitions: Some Preliminary Remarks on the Founding Gestures of the New Materialism." European Journal of Women's Studies 15 (1): 23-39.

Ahmed, Sara. 2014. "White Men." Feministkilljoys (Blog), November 4. https://feministkilljoys.com/2014/11/04/white-men/.

Anzaldúa, Gloria. 1987. Borderlands/La Frontera: The New Mestiza. San Francisco: Aunt Lute Books.

Anzaldúa, Gloria. 2015. Light in the Dark/Luz En Lo Oscuro: Rewriting Identity, Spirituality, Reality. Durham, North Carolina: Duke University Press.

Arendt, Hannah. 1958. The Human Condition. Chicago: University of Chicago Press.

Bayat, Asef. 2013. Life as Politics: How Ordinary People Change the Middle East. Stanford: Stanford University Press.

Buckley, Cheryl. 1986. "Made in Patriarchy: Toward a Feminist Analysis of Women and Design." Design Issues 3 (2): 3-14. https://doi. org/10.2307/1511480.

Clerke, Teena. 2010. "Gender and Discipline: Publication Practices in Design." Journal of Writing in Creative Practice 3 (1): 63-78.

Deleuze, Gilles. 1995. Difference and Repetition. Translated by Paul Patton. New York: Columbia University Press.

Dilnot, Clive. 2015. "The Artificial and What It Opens towards." In Design and the Question of History, edited by Clive Dilnot, Susan Stewart and Tony Fry, 165-203. New York: Bloomsbury Academic.

Dilnot, Clive, Susan, Stewart, and Tony Fry, eds. 2015. Design and the Question of History. New York: Bloomsbury Academic.

Dussel, Enrique. 2003. Philosophy of Liberation. Eugene: Wipf \& Stock Publishers. 
Ejército Zapatista de Liberación Nacional. 1996. "Cuarta Declaración de La Selva Lacandona." EZLN. http://palabra.ezln.org.mx/comunicados/1996/1996_01_01_a.htm.

Escobar, Arturo. 2012. "Notes on the Ontology of Design." http://sawyerseminar.ucdavis.edu/files/2012/12/ESCOBAR_Notes-on-theOntology-of-Design-Parts-I-II-_-III.pdf.

Escobar, Arturo. 2015. "Transiciones: A Space for Research and Design for Transitions to the Pluriverse." Design Philosophy Papers 13 (1): 13-23.

Escobar, Arturo. 2017. "Response: Design for/by [and from ] the 'Global South.'.' Design Philosophy Papers 15 (1): 39-49. doi:10.1080/14487136.2017.1301016.

Escobar, Arturo. Forthcoming. Designs for the Pluriverse: Radical Interdependence, Autonomy, and the Making of Worlds. Durham, North Carolina: Duke University Press. March 2018. https://www.dukeupress.edu/designs-for-the-pluriverse/?viewby=title.

Fanon, Frantz. 1971 (1961). The Wretched of the Earth. Harmondsworth, Middlesex: Penguin.

Fanon, Frantz. 1986 (1952). Black Skin, White Masks. New York: Grove Press.

Freire, Paulo. 2000 (1970). Pedagogy of the Oppressed. Translated by Myra Berman RamosNew York: Continuum.

Fry, Tony. 2009. Design Futuring: Sustainability, Ethics and New Practice. Oxford: Berg.

Fry, Tony. 2011. Design as Politics. Oxford, England: Berg.

Fry, Tony. 2012. Becoming Human by Design. London: Berg.

Fry, Tony. 2017. Remaking Cities: An Introduction to Urban Metrofitting. New York: Bloomsbury Academic.

Glick Schiller, Nina, and Andreas Wimmer. 2002. "Methodological Nationalism and beyond: Nation-State Building, Migration and the Social Sciences." Global Networks: A Journal of Transnational Affairs 2 (4): 301-334. doi:10.1111/1471-0374.00043.

Graham, Mary. 2017. "Sovereignty of Indigenous Knowledge." Symposium Talk presented at the Sovereignty of Indigenous Knowledge, Ballina, New South Wales, Australia.

Grosfoguel, Ramón. 2011. "Decolonizing Post-Colonial Studies and Paradigms of Political-Economy: Transmodernity, Decolonial Thinking, and Global Coloniality." TRANSMODERNITY: Journal of Peripheral Cultural Production of the Luso-Hispanic World 1 (1). http:// escholarship.org/uc/item/21k6t3fa

Grosfoguel, Ramón. 2013. "The Structure of Knowledge in Westernized Universities: Epistemic Racism/Sexism and the Four Genocides/Epistemicides of the Long 16th Century." Human Architecture: Journal of the Sociology of Self- Knowledge 11 (1): 73-90.

Knowles, Solange. 2016. A Seat at the Table. Record. Los Angeles: Saint Records and Columbia Records.

Lugones, María. 2007. "Heterosexualism and the Colonial/Modern Gender System." Hypatia 22 (1): 186-209. https://doi.org/ 10.1111/j.1527-2001.2007.tb01156.x 
Maldonado-Torres, Nelson. 2007. "On the Coloniality of Being." Cultural Studies. 21 (2-3): 240-270.

Mellick Lopes, Abby. 2005. Ecology of the Image. PhD dissertation. University of Sydney, Sydney, Australia.

Mignolo, Walter. 2011. The Darker Side of Western Modernity: Global Futures, Decolonial Options. London: Duke University Press.

Mitropoulos, Angela. 2006. "Precari-us." _Mute_ 1 (29). http://www. metamute.org/editorial/articles/precari-us.

Olsson, Göran. 2014. Concerning Violence. Documentary. Dogwoof

Oyewùmí, Oyéronké. 1997. The Invention of Women: Making an African Sense of Western Gender Discourses. Minneapolis: University of Minnesota Press.

Petzen, Jennifer. 2012. "Contesting Europe: A Call for an AntiModern Sexual Politics." European Journal of Women's Studies 19 (1): 97-114.

Ray, Katerina Rüedi. 2001. "Bauhaus Hausfraus: Gender Formation in Design Education." Journal of Architectural Education 55 (2): 73-80. doi:10.1162/104648801753199491.

Rooney, Ellen. 1989. Seductive Reasoning: Pluralism as the Problematic of Contemporary Literary Theory. Ithaca, New York: Cornell University Press.

Sheehan, Norman. 2004. Indigenous Knowledge and Higher Education. PhD dissertation. The University of Queensland, Brisbane, Australia.

Sousa de Santos, Boaventura. 2014. Epistemologies of the South: Justice against Epistemicide. Boulder: Paradigm Publishers.

Stiegler, Bernard. 2009. Technics and Time 2: Disorientation. Stanford, California: Stanford University Press.

Tonkinwise, Cameron. 2015. "Just Design: Being Dogmatic about Defining Speculative Critical Design Future Fiction." Cameron Tonkinwise (Blog), August 21. https://medium.com/@camerontw/ just-design-b1f97cb3996f\#.4725ehd06.

Tuck, Eve, and K. Wayne Yang. 2012. "Decolonization is Not a Metaphor." Decolonization: Indigeneity, Education \& Society 1 (1):1-40.

Virilio, Paul. 2008. Open Sky. Translated by Julie Rose. Radical Thinkers. London: Verso.

Virilio, Paul. 2012. The Administration of Fear (Intervention \#10). Translated by Ames Hodges and Bertrand Richard. Los Angeles: Semiotext(e).

Willis, Anne-Marie. 2006. "Ontological Designing - Laying the Ground." Design Philosophy Papers 4 (2): 69-92.

Willis, Anne-Marie. n.d. "Ontological Designing." Design Philosophy Papers. Accessed March 23, 2017. https://www.academia. edu/888457/Ontological_designing.

Zubaida, Sami. 2011. Beyond Islam: A New Understanding of the Middle East. London: I.B. Tauris. 


\section{What Is at Stake with Decolonizing Design? A Roundtable}

\section{Tristan Schultz, Danah Abdulla, Ahmed Ansari, Ece Canlı, Mahmoud Keshavarz, Matthew Kiem, Luiza Prado de O. Martins \& Pedro J.S. Vieira de Oliveira}

To cite this article: Tristan Schultz, Danah Abdulla, Ahmed Ansari, Ece Canlı, Mahmoud Keshavarz, Matthew Kiem, Luiza Prado de O. Martins \& Pedro J.S. Vieira de Oliveira (2018) What Is at Stake with Decolonizing Design? A Roundtable, Design and Culture, 10:1, 81-101, DOI: 10.1080/17547075.2018.1434368

To link to this article: https://doi.org/10.1080/17547075.2018.1434368

$$
\text { 电 Published online: } 28 \text { Feb } 2018 .
$$

\section{Submit your article to this journal ๔}

Џlll Article views: 1047

View Crossmark data ¿

Citing articles: 1 View citing articles 4 